University of Pennsylvania Carey Law School

Penn Law: Legal Scholarship Repository

Faculty Scholarship at Penn Law

$12-10-2003$

\title{
Social Welfare, Human Dignity, and the Puzzle of What We Owe Each Other
}

Amy L. Wax

University of Pennsylvania Carey Law School

Follow this and additional works at: https://scholarship.law.upenn.edu/faculty_scholarship

Part of the Ethics and Political Philosophy Commons, and the Social Welfare Law Commons

\section{Repository Citation}

Wax, Amy L., "Social Welfare, Human Dignity, and the Puzzle of What We Owe Each Other" (2003). Faculty Scholarship at Penn Law. 12.

https://scholarship.law.upenn.edu/faculty_scholarship/12

This Article is brought to you for free and open access by Penn Law: Legal Scholarship Repository. It has been accepted for inclusion in Faculty Scholarship at Penn Law by an authorized administrator of Penn Law: Legal Scholarship Repository. For more information, please contact PennlawIR@law.upenn.edu. 


\title{
SOCIAL WELFARE, HUMAN DIGNITY, AND THE PUZZLE OF WHAT WE OWE EACH OTHER
}

\author{
AMY L. WAX
}

In a recent book about the American anti-poverty movement, Joel Schwartz argues that the moral improvement of the poor was a central goal of anti-poverty reformers in the $19^{\text {th }}$ and early $20^{\text {th }}$ centuries. Although moral reform was considered intrinsically valuable, it was also thought to be instrumental. The emphasis on the character and personal conduct of the poor during this period was directed primarily at "reduc[ing]. . . dependence on either charity or government relief." The vices these reformers decried-“indolence, intemperance, improvidence-were attacked because of their role in fostering or exacerbating dependence," and good behavior "was largely synonymous with behavior furthering self-reliance." The twin aims of reducing dependence and fostering self-reliance account for many features of the early anti-poverty movement in this country. Those goals shaped the moral outlook of reformers, informed their recommendations, and determined which efforts were endorsed to help the less fortunate.

Anti-poverty policy has come a long way in the past century, in some ways returning full circle to its moralistic roots but in others departing from them never to return. There has been increased willingness recently, at least in some quarters, to decry "dependence" on the government in the form of reliance on cash entitlement programs or handouts. That willingness has found concrete expression in the reforms enacted in the Personal Responsibility and Work Opportunity Act in 1996, which imposes strict time limits and work participation requirements on recipients of public aid. But a century of theory and politics has transformed the call for reduced dependence-at least in its public guise-into one that is less moralistic and more pragmatic. That transformation reflects a deep

Professor of Law, University of Pennsylvania Law School.

1. Joel SCHWARTZ, Fighting POVERTy With ViRTUE: MORAL REFORM AND AMERICA'S URBAN POOR, 1825-2000, at 7 (2000).

2. Id. 
ambivalence about public moralism generally and moral prescription specifically. ${ }^{3}$ It is also rooted in a growing conceptual uncertainty about the roles of dependence and self-reliance in a modern, marketdriven society.

As Alan Wolfe documents in his book One Nation, After All, moralism - and especially public moral exhortation-has fallen out of fashion over the past 50 years. ${ }^{4}$ Very few public figures are willing to assert unequivocally that some ways of life and some types of character are "better" than others, to identify particular values as central to the good life, or to tell others which personal mores they should adopt. The stance translates into unease about holding up the so-called bourgeois values-those values associated with the Protestant work ethic - as the ones the poor should strive to adopt. Although welfare reform efforts have spawned some (mostly private) programs that attempt to get the poor to adopt habits that will help them be more economically successful (including the very practices associated with the Protestant ethic), the government rarely endorses or "preaches" bourgeois values to the poor outright, and certain of those values - such as sexual continence, cleanliness, marital fidelity, and frugality-are not considered fit subjects for official (or unofficial) public exhortation.

Furthermore, the very idea of economic self-reliance has become the target of a sustained, multi-pronged attack. Old guard proponents of welfare rights have long cast aspersions on the idea of economic "self-sufficiency," arguing that the notion is an incoherent and cruel conceit in the context of an intricate and intrinsically interdependent system. For some, the principle sources of poverty are obviously "structural” rather than "personal." For others, the lack of rhyme or reason in the rewards that markets assign to participants and the key roles played by luck and unearned endowments in determining economic success fatally undermine the ideological basis for valorizing "self-reliance." Practical economic realities of competitive employment markets also play a role in this skepticism. The intransigence of low pay for unskilled workers has forced an acknowledgment that good habits and conscientious efforts may not always be enough to guarantee workers' economic self-sufficiency.

3. See generally Alan Wolfe, One NATION, After All: What MidDle-Class AMERICANS REALLY THINK ABOUT GOD, COUNTRY, FAMILY, RACISM, WELFARE, Immigration, HomoseXuality, Work, THE Right, THE LEFT, AND EACH OTHER (1998).

4. Id. 
The general antipathy to public moralism, along with doubts about whether the economic independence of workers is either coherent or achievable, have taken their toll. The result is that the behavior and personal failings of the poor are de-emphasized, and the importance of good moral character to economic success is downplayed rather than trumpeted even by those most eager to reduce economic dependency. Reducing reliance on government handouts is depicted, at least for mainstream political consumption, as a goal primarily to be effected by wise policy design and proper administration, rather than by personal moral reform. Moreover, in recognition of the very real difficulties unskilled persons have in making ends meet, the goal for many of the poor-at least in practice-is no longer complete self-reliance. Although many former recipients of welfare have left the rolls voluntarily and assistance has been withdrawn from others, welfare reform has seen a proliferation of programs designed to supplement and support recipients' work efforts. Between the alternatives of welfare or work lies a realm of welfare plus work in which many of the poor have come to rest, at least for the time being.

This essay seeks to rescue the goals of economic self-reliance and independence from those who would discredit those objectives to cast aspersions on work-based welfare reform and endorse a return to unconditional redistribution. ${ }^{5}$ These voices repeatedly stress that no member of society can possibly hope to achieve self-reliance in the sense of complete personal and economic independence from others. Those who advance these critiques ask, in effect, "What is so wrong with dependence?" After all, everybody's doing it. Children are dependent on parents and caretakers; stay-at-home moms on husbands; widows on their husband's social security benefits; students on government loans; homeowners on mortgage interest tax deductions; and the idle rich on inherited trust funds. Every living person is dependent on the efforts and innovations of generations past. Indeed, everyone currently alive is in some sense dependent on everyone else in that virtually no one alone can supply what he or she uses and needs in everyday life. Moreover, everyone looks to the government to provide collective goods, basic infrastructure, and protection from force or fraud. In short, dependence is everywhere. Since we accept these interrelationships as unobjectionable and in many cases desirable, it is difficult to say what is wrong with

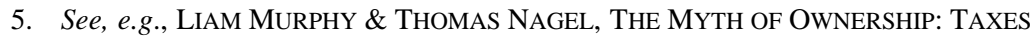
AND JUSTICE 76-95 (2002). 
dependency as such. Ergo, there is no principled basis for objecting to the dependence of the poor, including single mothers now subject to work requirements under the federal Temporary Assistance for Needy Families program. ${ }^{6}$ The very same arguments can be restyled, ceteris paribus, as attacks on the notion of "self reliance." No one is "selfreliant" in the sense of being able to do without others' efforts or resources. Hence the notion of "self-reliance" is a chimera that cannot stand as the touchstone for public policy in this area or any other.

In its avatar in the realm of political theory, this line of reasoning starts with an attack on the notion of personal desert. Someone is ordinarily thought to "deserve" credit or reward for the products of his efforts. But almost no one produces anything alone, and everyone's performance depends on others. Because it is difficult to calibrate individual contributions to output, it is difficult to argue that individuals "deserve" the compensation they receive for particular jobs performed. The impossibility of parsing out personal credit for production compounds the arbitrariness of market structures. Markets seem unfair because they assign rewards based in large part on endowments (such as looks or talent), or the vicissitudes of demand, for which individuals cannot claim credit. These insights fuel a rejection of economic individualism and the embrace of a holistic view of society, which sees all outcomes as ultimately collective and all production as, at bottom, a group effort. This holistic view, which goes along with the notion that no one can make an elemental claim of entitlement to his earnings in a modern economy, suggests that the very idea of individual desert is incoherent.

Yet another expression of this view begins with an attack on the distinction between the public and private spheres. Legal theorists such as Cass Sunstein note that the private exchanges and agreements comprising the market economy depend on the collective maintenance of public institutions and the enforcement of rules of contract and tort. Likewise, the existence and integrity of private property depend on the government's willingness to protect the security of property rights. According to this view, it is not possible to identify a pre-existing "baseline" state of affairs that pre-dates the

6. For examples of arguments in this ilk, see generally EVA FEDER KITTAY, LOVE'S LABOR: ESSAY ON WOMEN, EQUALITY, AND DEPENDENCY (1999); Martha A. Fineman, The Nature of Dependencies and Welfare "Reform," 36 Santa Clara L. Rev. 287 (1996); Martha Minow, The Welfare of Single Mothers and Their Children, 26 Conn. L. Rev. 817 (1994).

7. See Samuel Scheffler, Justice and Desert in Liberal Theory, 88 Cal. L. Rev. 965 (2000). 
creation of an effective governing structure and the enforcement of legal rules. It follows that no distribution of wealth or resources can be regarded as a natural or "pre-legal" entitlement. All allocations are, in some sense, the creatures of the community because they cannot be maintained without the community's help and support.

This line of reasoning is enlisted to discredit the longstanding distinction between positive and negative rights and to defend distributive programs against libertarian claims of private entitlement. The logic goes like this: what the government creates and supports it is free to disturb. ${ }^{8}$ That everyone is in some sense dependent on the government for the resources at his disposal means that there is no principled limitation on redistribution of resources from the "haves" to the "have-nots." Since no one is exclusively responsible for producing what he possesses, it follows that the government can reallocate those possessions to others as it chooses. Because there is no defensible, systematic connection between effort and reward, there is no basis for complaining of transfers to those who work less hard, or even not at all, and no basis for holding up economic "independence" as a morally praiseworthy goal. Pragmatic concerns alone limit what the government can and should do in the realm of resource distribution.

Finally, the voices of feminist theorists can be heard in a similar refrain. Feminists frequently make the point that every person's efforts, and the rewards that follow, ultimately rest on someone else's contribution. The care received by individuals in childhood from parents and others is indispensable to their ability to generate resources or to contribute to the social product. Because no one alive has failed to benefit from others' care-which has been rendered to them, in effect, free of charge-no one can claim entitlement to the full value of what he or she produces. By focusing on the pervasiveness of dependency within families, and in particular the ineluctable dependence of children on parents, feminists cast aspersions on the very possibility of self-sufficiency. Moreover, in their emphasis on the web of interdependencies and the role of domestic, unpaid "care work" as the precondition for all production, feminists implicitly repudiate the market as the sole test of value. This implies that the distribution mandated by the market is not inviolate and further buttresses the case for a free hand in redistribution to the

8. See, e.g., Cass R. Sunstein, Lochner's Legacy, 87 Colum. L. Rev. 873 (1987); DAVID KELLEY, A LIFE OF ONE'S OWN: INDIVIDUAL RIGHTS AND THE WELFARE STATE (1998); MURPHY, supra note 5. 
"non-working” poor. In sum, because "self-reliance" is not only regarded as incoherent, but also as deeply antithetical to their interests and values, feminists are hostile to its role as a motivating objective of public policy.

Indeed, many feminists go further in contending that the failure to redistribute resources generated within markets to those outside itincluding the single mothers and children who were formerly the recipients of unconditional largesse-is itself unjust. In their attempt to broaden the category of persons who are regarded as "deserving" of society's approbation and material support, feminists note that welfare work requirements slight the kinds of domestic and caretaking tasks traditionally performed by women. Because many nonworkers with whom the welfare system is concerned are caretakers of young children, critics maintain that welfare work rules threaten to burden women disproportionately and to discourage the performance of non-monetized domestic functions. Indeed, the crux of the debate over how the welfare system should treat "caretaking units"-usually single mothers and their children-centers on what should count as "work." The oft-heard claim is that caretaking performed without pay is no less socially useful than work performed for wages and should therefore be rewarded. Society should offer collective support to those who care for others. ${ }^{9}$ In making these arguments, feminists attempt to draw strength from the observation that society sanctions, and even approves, economic dependence within traditional families, including the dependence of homemaker mothers on breadwinner husbands. They ask why welfare mothers' dependency on the government should be eliminated but the dependency of wives and mothers - who perform the very same domestic tasks - should be preserved. Likewise, no voice is raised against non-working, widowed mothers receiving social security benefits on the accounts of their deceased or disabled breadwinner

9. See generally ANn AlstotT, No EXIT: WhAt PARENTS OWE THEIR CHILDREN AND WHAT SOCIETY OWES PARENTS (forthcoming 2004); SHIRLEY P. BURGGRAF, THE FEMININE ECONOMY AND ECONOMIC MAN: REVIVING THE ROLE OF FAMILY IN THE Post-Industrial Age (1997); ANN CRITTENDEN, THE PRICE OF MOTHERHOOD: WHY THE MOST IMPORTANT JOB IN THE WORLD IS STILL THE LEAST VALUED (2001); MARTHA

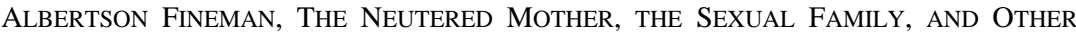
Twentieth CENTURY TRAgedies 213-17 (1995); KitTAY, supra note 6; Martha Nussbaum, Disabled Lives: Who Cares?, N.Y. Rev. Books, Jan. 11, 2001; Elizabeth Anderson, What is the Point of Equality, 109 Ethics 287 (1999). For a cogent critique of the feminist "ethic of care," see WILL KYMLICKA, CONTEMPORARY POLITICAL PHILOSOPHY: AN INTRODUCTION 398-422 (2d ed. 2002). 
spouses. ${ }^{10}$ Many of these women do no work in the paid economy and are thus no more "self-sufficient" and no less dependent than single, never-married mothers on welfare. Yet the public is far more forgiving of "dependence" for the former than the latter circumstance.

The arguments rehearsed above turn on a basic reductio ad absurdum: since no one is entirely self-sufficient and many are completely dependent on others, how can self-sufficiency be demanded of recipients of public aid? The contention is that there is no principled way to distinguish, either in degree or in kind, among those who rely on other persons' efforts and resources. It follows that there is no basis for distributive policies that accord different treatment to people who work and those who do not.

Despite its ostensible defiance of common sense-and its rejection of everyday political instincts-this line of reasoning is taken seriously by many. It cannot be dismissed out of hand and, indeed, poses an important challenge to work-based welfare reform. It must be acknowledged that the proponents of this view make a valid point in one respect: dependence and self-reliance are terms that are often used carelessly by those hostile to economic redistribution. Viewing these states as absolutes rather than as matters of degree creates an opening for those who would discredit the commonsense distinctions - made frequently by ordinary people - that justify imposing welfare work requirements.

The challenges and examples that are routinely invoked to disparage calls for self-sufficiency and economic "independence" suggest that the defense of welfare reform must take a more nuanced form. The simpleminded shorthand of the announced objectivesabolishing dependency, achieving self-sufficiency_are politically useful in the age of sound-bites and brief attention spans. But the concepts in their unembellished form are vulnerable to attack. If the welfare reform project is sound and worthy-which this author believes it is-then a more conceptually coherent defense of recent changes in policy should be available. The question is, how can that defense be constructed?

A careful reading of Joel Schwartz's book on the history of poor relief reveals that the moral reformers of the past understood and anticipated the critiques of the simple-minded exhortations of selfreliance and independence that troubled so many "liberal" champions of the poor today. These reformers understood very well that the term

10. See, e.g., Minow, supra note 6. 
"self-reliance" was not to be taken literally, but rather was a shorthand for a particular type of constructive role in community and economic life. They knew as well that all persons in society are in some sense "dependent," or, more accurately, interdependent. Thus, achieving complete "self-reliance" and eliminating "dependency" wholesale are impossible and, indeed, ultimately incoherent objectives. The false dichotomy between dependence and independence does violence to what supporters of the poor aim to achieve. Rather, the concepts of dependence and self-reliance must be understood as having a "social meaning" that does not rest on conceptually pure absolutes, but rather on the fulfillment of normative expectations regarding conduct and participation in social and economic life.

Champions of welfare reform thus cede no important ground to opponents by acknowledging that self-sufficiency is never complete and that economic independence for poor families - as for everyone else-cannot be all or nothing. Yet they must continue to insist firmly that this provides no warrant for returning to the failed experiments of the past. Reformers must stress the simple truth that economic independence and self-sufficiency are matters of kind and degree, and that meaningful and justifiable distinctions between types of dependency can and must be made. The fact that self-reliance can never be complete does not make it an unworthy or unimportant goal; nor does it undermine the value of striving to increase our efforts to become economically less dependent. The fact that self-support can never be absolute does not mean it should not be maximized as much as possible. The fact that dependency is a fact of life, and is sometimes unavoidable or even desirable, does not mean that dependency should be indulged or accepted in all cases. Admittedly, this more qualified and complicated stance, although responsive to the realities of economic life, renders arguments in favor of welfare reform harder to make and demands a more nuanced theory. There is no avoiding, however, the need to take these qualifications into account.

How might more effective arguments for minimizing economic dependency and maximizing self-sufficiency be constructed? One approach would look to the distinctions ordinary people make between constructive citizenship and social parasitism. The challenge is to give the idea of constructive citizenship definite and rigorous content - content that can serve as a practical and useful guide to wise policy and that can also withstand theoretical attacks that seek to 
discredit work-based reforms. That challenge can be met, in my view, by making use of the concept of conditional reciprocity.

I have previously explored the idea of conditional reciprocity as a principle of social organization that commands widespread support in the United States and in modern industrial societies. It is generally acknowledged that people cannot always achieve complete selfsufficiency and that there are occasions when individuals may call upon help from others. The collective, through government and private charity, stands willing to pledge support to its members during periods of economic misfortune or distress. In exchange, however, group members are regarded as owing a duty not to call upon public aid unnecessarily. The expectation is that people will strive to achieve self-support through their own reasonable efforts in the labor market and will fall back on group assistance only if they are unable to attain self-sufficiency or fall short through no fault of their own. ${ }^{12}$

Conditional reciprocity as an animating principle for social welfare policy offers advantages over a one-dimensional and absolutist commitment to economic self-reliance. First, it makes room for the undeniable reality that individuals are interdependent in myriad ways - the very reality that makes simplistic stress on the goal of economic "independence" problematic and vulnerable to attack. The insight that individual effort, and the fruits of that effort, depend on the past and present contributions from others is in no way inconsistent with a reciprocal ideal. Rather, that ideal acknowledges the importance of the collective and assigns a role to group support. But the reciprocal ideal incorporates the understanding that group vitality depends critically on establishing ground-rules for the give and take of group living. Those rules are necessary to minimize unfair and destructive free-riding, which are inimical to the group's continuing economic health and survival and the willingness of members to participate. For this reason, many societies have recognized the duty of the able-bodied to contribute to self-support as a pre-condition to looking for material assistance from the group.

Second, conditional reciprocity, in reflecting commonplace views about welfare, desert, dependency, blame, and socially constructive roles, maps onto the political consensus behind welfare reform. Public

11. See generally STEVE FARKAS ET AL., THE VALUeS We LIVE BY: WHAT AMERICANS WANT FROM WELFARE REFORM (1996); MARTIN GILENS, WHY AMERICANS HATE WELFARE: RACE, MEDIA, AND THE POLITICS OF ANTIPOVERTY (1999).

12. See Amy L. Wax, Disability, Reciprocity, and Real Efficiency: A Unified Approach, 44 Wm. \& Mary L. Rev. 1421, 1428 (2002). 
opinion polls show that voters are not unequivocally opposed to economic redistribution. Rather, they are willing to spend moneyoften a lot of money-to help move persons from welfare to work. They are far less willing to provide public funds to help those who make no socially acceptable effort.

Third, the paradigm also helps explain the difficulties posed by "hard cases" and borderline categories-such as single mothers of young children - which generate so much ambivalence, confusion, and controversy in the welfare policy arena. In addressing those "hard cases," the ideal helps us understand that some issues admit of no eternally valid "right answers" but require ongoing sensitivity to social context, conventions, and expectations concerning what constitutes a "reasonable" effort or contribution on the part of various individuals within society. Conditional reciprocity makes room for shifts over time in notions of what individuals owe to each other as conventions and ideas about reasonable effort respond to changed circumstances. In some cases, such as how to deal with single mothers, logic chopping and conceptual analysis from first principles is not very helpful in resolving the issue of how social resources should be applied since conventional expectations surrounding work, motherhood, and reproduction have evolved in complex ways. The reciprocity paradigm takes account of that evolution and provides a framework for pragmatically assessing competing factors in determining whether mothers should be expected to work and under what circumstances.

Finally, conditional reciprocity can accommodate the economic and social reality, which reflects the operation of real world labor markets, that not everyone can achieve self-sufficiency and economic independence despite reasonable efforts. In those circumstances, the reciprocal ideal mandates that the government provide social and financial assistance with the ultimate goal of making up the difference between what individuals can earn on their own and what is necessary for a reasonably dignified existence. The goal is to allow everyone who works to achieve a basic, minimum standard of living. The idea is also consistent with policies, such as transportation and child-care subsidies to working families and the Earned Income Tax Credit, that are designed to "help those who help themselves." These policies have, if anything, grown in importance as welfare reform has proceeded.

The reciprocal ideal, by eschewing absolutes and refusing to hypostatize the polar extremes of self-sufficiency and dependency, is 
thus better equipped to deal in principled ways with attacks on workbased welfare reform that are premised on the argument that, because economic dependence is pervasive, the government acts arbitrarily in seeking to reduce or penalize the dependence of the poor on government help. The paradigm of conditional reciprocity shows that not all forms of dependence are equivalent and that the government's interest in minimizing economic dependency among the non-working poor is not arbitrary at all. By making the offer of group assistance conditional on the individual's "best efforts," this principle helps explain why some forms of economic dependence are regarded as benign, or even desirable, while others evoke disapproval. It also helps shed light on various aspects of the politics of social welfare programs.

Social security for the elderly and programs for the disabled, for example, are famously popular. Both of these programs pay benefits to individuals who have performed a minimum amount of work in the paid economy and have paid some portion of their wage into a collective fund over time. In the case of the elderly, social security is generally considered a government-administered insurance program in which individuals put aside money for their own retirement. Although the view of social security as analogous to private insurance is an unrealistic conceit-since the program operates on a highly redistributive pay-as-you-go basis with recipients drawing out far more than the present value of what they paid in-the underlying intuition behind the commonplace view comports with a reciprocal ideal: elderly individuals are regarded, through past efforts, as having "earned" the right to a minimally decent level of support from society for their remaining years on earth. The operation of the reciprocity paradigm in this case, however, is a mixed blessing. Indeed, this notion hinders attempts to scale back social security benefits to relieve the burden on a shrinking population of working-age adults and to put the program on a more actuarially sound basis.

The situation is similar for disability insurance programs: individuals are regarded as entitled to support from the collective when a disability renders them unable to support themselves. Indeed, entitlement to disability benefits through, for example, the federal Supplemental Security Income (SSI) program is not regarded as dependent on any past or present contribution or work history. The willingness to extend public support to the medically disabled responds to the realization that most people are disabled through no fault of their own. The reciprocity paradigm only requires individuals 
to attempt to support themselves through work if they can. That is, even the condition of reasonable effort is, in effect, conditional. The group is willing to help persons who cannot work productively so long as that limitation is due to a condition outside their control. ${ }^{13}$

Old age insurance and disability benefits programs also provide support for dependent family members, wives, and widows, regardless of whether those beneficiaries work in the paid economy. Yet those payments are politically popular and fail to elicit the degree of voter hostility that has been directed towards programs that pay benefits to non-working single mothers and their children, such as Aid to Families with Dependent Children. Why does the public smile on benefits for a (non-working) widow of a disabled or deceased worker but frown on payments to a single never-married mother even though both are dependent on government "handouts" and neither contributes to self-support through paid employment? ${ }^{14}$ Is the best explanation, as some have suggested, hostility to the poor or simple racism? Conditional reciprocity casts doubt on this uncharitable view. The contributions of workers that entitle them to draw on public funds in the event of inability to work does not just extend to individuals, but is regarded as covering their immediate families. Because a worker's efforts are designed to support and protect his kin, the group is willing to pledge to take on the responsibility when the worker is no longer able. Key to that willingness is the understanding that private, consensual reciprocity within families is benign and even desirable. Non-working wives are regarded as having engaged in a voluntary — and presumably valuable - private exchange of services with their working husbands. The fact that each member of the couple is willing to continue with the arrangement shows that each is making a positive contribution to the other. In the economists' parlance, the readiness to engage in the voluntary exchange of resources and services indicates that the deal is Pareto-superior for both parties. By definition, such family arrangements do not resemble the type of "free riding" that past societies took pains to minimize in order to maintain stability and survival. Rather, these are private deals for ongoing mutual gain, generating net utility, well-being, and value. Although a non-working wife in a traditional breadwinner family is thus

13. To be sure, disability benefits are sometimes forthcoming for conditions to which the individual sufferer contributed through carelessness or poor habits. As a reflection of the public's unease about such aid, the law has been changed in recent years to cut back, for example, on benefits for those addicted to drugs and alcohol.

14. See Minow, supra note 6 at 826-31. 
"dependent" on her husband for financial support, her husband is also dependent on her for services and affection. The "dependency" of the homemaker wife in traditional married couples thus is very different in its social consequences and effects from the dependency of nonworking individuals (and their children) on the group as a whole.

This logic can be extended to the provision of survivor's and widow's benefits under social security, with the additional understanding that the exchange inherent in the relationship takes place through a transfer of resources over time. The breadwinner works and makes contributions to the Social Security fund, but part of what a breadwinner "insures" against - in the sense of establishing his claim on a minimum social quid pro quo-is the destitution of his beloved family members. That is, what a husband "buys" through the system is the right to transfer some of his entitlement to minimum support to his spouse after death. The benefits paid to a wife-which allow her to refrain from working - can thus be seen as a property right to the husband. In any event, that transfer is not regarded as an instance of "free riding" by the widow on society as a whole. Rather, the widow has "carried her weight" by occupying her role within the reciprocal and consensual structure of family exchange. This logic is also pertinent to the tolerance-albeit with greater ambivalence-of individuals who live off inherited wealth. Although the idle rich make no positive contribution through their own work or effort, they do not call unnecessarily upon the group for collective support. Rather, they are the lucky beneficiaries of a private transfer of wealth that has nothing to do with free riding on the group.

Viewing the structure of welfare as rooted in the historical conditions that enabled voluntary cooperative arrangements for mutual support to survive and thrive explains much about attitudes towards different types of dependency and why attempts to equate them are rejected by most voters. The examples given above illustrate that non-work (or failure to work for pay) is not objectionable as such. Work on the market is not the absolute value or the ultimate test and dependency is not absolutely proscribed. Rather, the goal is to avoid the unnecessary expenditure of group resources set aside to insure against misfortune or emergencies. Individuals who ask for support from the group as a whole must make, or have made, an effort to support themselves, or must provide (or have at some point provided) something valuable, either to the public as a whole or to other private individuals who are willing to engage with them in exchange. Alternatively, individuals must have an excuse-such as 
inability due to a medical condition-for failure to fulfill these expectations. In short, every person must somehow "pull his load," and no one is allowed a "free ride."

This rule of thumb is not without ambiguity. That ambiguity accounts in part for shifting policies regarding public financial support for mothers of young children. As already noted, feminist critics of welfare reform object to a narrow definition of social contribution that regards work for pay as the only basis for desert. They insist that mothers of young children are providing "value added." Those who urge social support for caretaking, however, must supply a theory of compensation or social reciprocity that disposes of demands to support a range of other non-market activities. Graffiti artists, gardeners, school volunteers, and subway buskers would all lay claim to subsidy. Yet we harbor strong intuitions that society need not honor such claims. One argument in favor of collective support for caretakers and their charges holds that parents, through their children, generate a "public good" that confers uncompensated benefits on the public as a whole. ${ }^{15}$ Alternatively, Anne Alstott of Yale Law School argues that because society's obligations to children can only be properly discharged if parents provide intensive and continuous care, justice and pragmatism dictate that society support parents in fulfilling this obligation. ${ }^{16}$ Although there is limited political support for helping parents-as reflected, for example, in modest tax credits and childcare subsidies-most voters remain convinced that the primary responsibility for children must remain with their parents. That sentiment, combined with a dramatic movement of mothers into the labor force and social science data suggesting that single parenthood is detrimental to children, has turned the tide against no-strings-attached benefits for mothers of young children and in favor of expectations that they contribute to their own support through paid employment.

Finally, the paradigm of conditional reciprocity has implications for the idea that is central to this conference: human dignity. The recent success of efforts to impose meaningful work requirements as a condition for receiving public aid both proceeds from, and also fosters, a renewed appreciation of the inherent dignity of work. Conditional reciprocity rests on the understanding that everyone must

15. See NANCY FolBRE, THE INVISIBLE HEART: ECONOMICS AND FAMILY VALUES 53-82 (2001); Amy L. Wax, Something for Nothing: Liberal Justice and Welfare Work Requirements, 52 Emory L.J. 1 (2003).

16. See generally AlstoTT, supra note 9. 
contribute something in order to receive something in return. That "something" may be humble or modest. But humility and modesty do not in themselves detract from worthiness for inclusion in the collective or for help when the chips are down. Even the performance of the lowest-skilled jobs-including jobs that are sometimes disparaged to the poor by "welfare rights" advocates as demeaning or "dead end" — earns the community's respect and is viewed as vital to its integrity.

The logic of conditional reciprocity also suggests that a dignified existence is one that balances dependence and independence, competition and cooperation. Human dignity is not a matter of extremes and is no more achieved through complete self-sufficiency than through abject and idle dependency. "Self-sufficiency," taken at its word, conjures up the Hobbesian nightmare of the suspicious hermit, with a life solitary, poor, nasty, brutish, and short. Cooperation is the watchword of successful societies everywhere, and no one fails to benefit from the efforts, work, generosity, and good will of myriad others. The crux of a dignified existence is thus not "independence," but a constructive dependency that abides by wellrecognized rules of conduct-rules that include a reluctance to engage in needless exploitation of others. The better and more accurate term is "interdependency," which suggests mutual and consensual support and contribution. To be sure, the institutional structures that best strike the balance between dependence and independence are not always obvious and vary under different conditions and circumstances. The creation of these structures is a political work in progress. Yet the fundamental paradigm is robust. The idea of conditional reciprocal obligation retains a remarkably tenacious grip on ordinary hearts and minds. It sheds a good deal of light on our feelings and attitudes towards those less fortunate and helps explain why we are sometimes willing to help and why that willingness sometimes runs out. It also offers guidance for the poor themselves and points their way towards the dignified existence that so often eludes them.

17. Myron Magnet, The Dream and the NightMare: The SiXties' Legacy TO THE UNDERCLASS (1993); LAWRENCE M. MEAD, BEYOND ENTITLEMENT: THE SOCIAL OBLIGATIONS OF CITIZENSHIP (1986). 